\title{
A THEOLOGICAL RESPONSE TO BIBLICAL VIOLENCE
}

\author{
Erika Barnard \\ Department of Old Testament and Hebrew Scriptures \\ University of Pretoria \\ Esias E. Meyer \\ Department of Old Testament and Hebrew Scriptures \\ University of Pretoria
}

\begin{abstract}
The overwhelming number of violent texts within the Old Testament raises serious theological and ethical problems for those who read the Bible in search of spiritual devotion and ethical direction. This article aims to explore one of the most ethically challenging texts in this regard - the conquest narrative in Joshua 6-11. An interdisciplinary study is presented in which social identity theory, the concept of hybridity and the role of courage and fear within an ancient community are discussed. This response is largely based upon the work of Baumann (2006) who also urges contemporary scholars to not only engage with the violent images within the Old Testament but also to earnestly seek to understand the functioning thereof within its original Ancient Near Eastern context.
\end{abstract}

Keywords: Joshua; Ban; Violence; Literary violence; Hybridity

\section{Introduction}

From the earliest of times religion and violence have been inseparably linked. Moreover, the majority of religious scholars would admit (sometimes uncomfortably) that not a single religious tradition can escape the inherent element of violence embedded within its nature (Seibert 2012:49; cf. Larson 2004:37; Ellul 1969:17). ${ }^{1}$

Our contemporary context of violence often spurs various local and international pleas for peace among Christians, most of which claim it to be the practical embodiment of what we understand to be at the "heart" of the biblical message. ${ }^{2}$ This perspective on the Bible, however, has proved to be nothing less than a one-dimensional redaction of the complex and diverse content of a canon that has been compiled over centuries and consists of literature comprising of various genres, each with its own envisaged audience.

In fact, much of this literature does not propagate the more palatable plea for peace that we so often propagate. When speaking about the content of the Old Testament

1 However, this relationship is not only a historical phenomenon. For even in our modern era, it is still relevant (if not more so) and is continually manifested in ongoing religious warfare between Israel and Palestine, and the increasing acts of religious terrorism in North Africa, the Middle East and Europe (Larson 2004:29-31; Seibert 2012:16-27; cf. Meyer 2011:1).

2 See, for example, the plea for peace and justice for aboriginal migrants in Taiwan, based on supposed Christian morals (Au 2012); The United Nations' concentrated efforts to encourage peace in Africa (Report of the Secretary General 1999); etc. 
specifically, one does not have to look very hard to find examples of slavery, racism, warfare, genocide, abuse of women and children, religious intolerance, capital punishment and even child sacrifice within its pages (Seibert 2012:2, 49; cf. Carter 1996:136; Meyer 2011:1). ${ }^{3}$

This overwhelming reality, which Seibert (2012:2) refers to as the Old Testament's "troubling legacy", constitutes a serious theological problem for those who read the Bible in search of spiritual direction and spiritual devotion - especially when one considers the many occasions on which these violent texts have been wrongfully used to legitimise and justify the same atrocious acts that we accuse it of. The outright misuse of Old Testament texts over centuries to justify acts of violence - all in the name of "scriptural authority" - ultimately distorts not only the aim and inherent character of the Old Testament, but also the character of God (Seibert 2012:16-25; cf. Collins 2005:10). As Docker (2008:124) rightfully states, many Old Testament texts implore us to ask: "Who or what is God?" For if God is revealed as a character who acts in a violent manner and who at times murders thousands of people, we have no choice but to ask ourselves what these actions have to say about the deity being portrayed.

This article, therefore, aims to highlight the theological problems that arise when one considers these violent Old Testament texts as equally important canonical literature as those beseeching peaceful conduct. In this attempt, the conquest narrative in Josh. 6-11 will serve as a revealing sample of literary violence that implores the reader to consider critically its overall message for a contemporary audience. ${ }^{4}$ In order to achieve this, various possible theological responses to literary violence in the Bible will be discussed. Of these, the approach of Bauman (2006) (which is considered by this article to be the most responsible in this regard) will be applied specifically to the conquest narrative in order to reveal its imperative function in ancient Israelite society.

An interdisciplinary socio-historical and socio-political study will be presented as part of the proposed methodology of Bauman (2006), in which the role of social identity, hybridity and the instilment of courage and fear, will be highlighted.

\section{The conquest of Canaan (Josh. 6-11) as literary violence}

Regarded by many as one of the most ethically challenging texts in the Old Testament, the conquest narrative in Josh. 6-11 serves as the grand finale in the greater narrative of the fulfilment of the promise that God made to Abraham regarding the provision of a "land of their own" (Dozeman 2015:3; cf. Seibert 2012:96). When God later calls Moses to free the Israelites from Egypt, the promise originally made to Abraham is repeated, and in Josh. 1:2 the final command concerning its fulfilment is pronounced (NRSV):

My servant Moses is dead. Now proceed to cross the Jordan, you and all this people, into the land that I am giving to them, to the Israelites.

Raymond Schwager (2018:3) remarks on more than 600 passages in the Hebrew Bible alone that speak explicitly of violence committed against nations or individuals - many not only condoning but even encouraging such violent acts.

4 Referring to violence that is portrayed through literature, even though it may or may not have any basis in historical reality itself (Barnard 2019:9). 
It is interesting to note, though, that in the canonically earlier texts referring to the promised land (i.e. Gen. 15:18-21; Gen. 26:3; Gen. 28:13; Ex.23:3; etc.), no mention is made of the fact that Canaan was still densely populated by the indigenous cultures. In fact, it is only in Deut. 7:1-2 that these cultures are mentioned for the first time regarding to Israel's upcoming quest (NRSV):

When the Lord your God brings you into the land that you are about to enter and occupy, and he clears away many nations before you - the Hittites, the Girgashites, the Amorites, the Canaanites, the Perizzites, the Hivites, and the Jebusites, seven nations mightier and more numerous than you - and when the Lord your God gives them over to you and you defeat them, then you must utterly destroy them. Make no covenant with them and show them no mercy.

This initial description of Israel's proposed entry into Canaan already clarifies that God himself will be acting as the Israelites' Protector and Commander-in-Chief who will "drive out before them" the nations that seem to stand in their way (Seibert 2012:96). And even though the (ban) is by now prescribed as the method by which the Israelites are to engage in this conquest, the details of their participation are pronounced only much later in Deut. 20:16-17 (NRSV):

But as for the towns of these peoples that the Lord your God is giving you as an inheritance, you must not let anything that breathes remain alive. You shall annihilate them - the Hittites and the Amorites, the Canaanites and the Perizzites, the Hivites and the Jebusites - just as the Lord your God has commanded.

The "herem" is specifically prescribed as a war tactic for Jericho, as the city is explicitly commanded to be "devoted to the LORD for destruction" in Josh. 6:16-17. Later, Josh. 8:24-28 recounts the slaughtering of all seemingly innocent inhabitants of $\mathrm{Ai}-\mathrm{a}$ city of which only the livestock were spared this ruthless fate. The divinely sanctioned violence continues in Josh. 10:28, where Joshua himself is said to have struck with his sword the city of Makkedah - murdering all inhabitants (including the king), as he also did to "the hill country and the Negeb and the lowland and the slopes, and all their kings" by the command of YHWH (Josh. 10:40). In the same way, the city of Hazor is said to have been destroyed - leaving no one alive (Josh. 11:11-12); as was the case with the Anakim whom Joshua and his men drove "from Hebron, from Debir, from Anab, and from all the hill country of Judah, and from all the hill country of Israel; Joshua utterly destroyed them with their towns" (Josh. 11:21). ${ }^{6}$

A divinely sanctioned form of violence found especially in the Hebrew Bible, calling for the absolute destruction of a particular group of people, along with their city and livestock (Seibert 2012:34; cf. Dozeman 2015:54, 56). Much has been written about the חרם and its many occurrences in the Hebrew Bible.

Throughout Josh. 6-11 specifically, this form of utter destruction becomes a central theme that is alluded to no less than 27 times in the text (Dozeman 2015:54).

6 However, different formulae of the term "herem" are evident throughout these examples: where the term is employed as a verb, it occurs only in the Hiphil and refers to the ritualised dedication of an object, individual or nation through total destruction and the act of war (Meyer 2018:72). When employed as a noun, these objects, individuals or nations are referred to as sacrifices under absolute law to be devoted to the 
Clearly this ruthless form of combat, all in the name of YHWH, seems quite common throughout the conquest narrative. Meyer (2018:74) provides a discussion on the different possible meanings ascribed to the חרם throughout the Hebrew Bible. First, he reminds us of the traditional argument that it is necessary to distinguish between a "war חרם "חרם and a "peace/cultic. This paradox in semantics has been examined and debated by many scholars over the past century. Some, such as Versluis (2016:241), aim to explain the apparent contrast by providing overly simplified explanations that claim "the meaning of the verb חרם to almost always belong to the semantic domain of destruction and devastation" while "the noun belongs to the domain of the sacred, indicating a certain sacral status of person or objects".

Others, such as Milgrom (2001), Tatlock (2006) and Niditch (1993), however, argue that since the noun and verb are often used in close proximity within the same text, a development in the history of the meaning of "herem" becomes evident, namely "the term that was originally employed in cases where it referred solely to destruction and annihilation of nations, individuals and objects", was "later influenced by priestly incentives to refer to people/objects that were holy, or set apart for the devotion of YHWH" (Meyer 2018:74-80).

Only two extra-biblical texts from the Ancient Near East (ANE) exist in which the exact same root חרם is found. Firstly, the well-known Moabite Mesha Inscription dating from the $9^{\text {th }}$ century BCE, describing in detail the triumph of King Mesha of Moab over Israel, as he utterly destroyed Nebo, along with thousands of men, women and children, all in the name of the Moabite god, Ashtar-Chemosh, serves as a good example of the way in which the term "herem" was also understood by other ancient cultures as referring to ritualised destruction as an act of devotion to a deity (Monroe 2007:322-325). Similarly, the RES 3945 (an old Sabian text in which the victory of Karib-ilu, a South Arabian Mucharib, is described) also refers to the חרם as destruction performed in dedication to the gods (Monroe 2007:322-325). It thus becomes clear that the notion of "utter destruction" was well known in the ANE. In the Royal Annals of Thutmose III there are detailed references to the king's annihilation of Canaanite cities described as follows: "Arrival at the town of Kadesh. Destroying it utterly. Felling its trees (and) cutting down its grain" (Wright 2015:149). Similarly, Ramses III also referred to the way that he had laid waste to the Libyan Meshwesh: "Their cities are made ashes, wasted and desolate" (Wright 2015:149). Another striking example appears in the annals of Sennacherib and Sargon II. With regard to Sargon's crusade against Metattati, it is written:

Their twelve strong and walled cities, together with eighty-four cities in their neighbourhood, I captured. I destroyed their walls, I set fire to the houses inside of them, I destroyed them like a flood, I turned them into mounds of ruins. (Wright 2015:149)

It accordingly becomes clear that literary portrayals of this ruthless form of warfare were not limited to the Israelites alone, and that they had no ethical reservations about applying

commanding God of the "ban” (Dozeman 2015:54; cf. Clines 1996:319; Van Dyk 2003:99). These sacrifices are devoted to the deity due to their "extremely valuable" nature - especially in the case of human sacrifice. 
this type of conduct themselves. Dozeman (2015:55) aptly remarks that according to the text "It is Yahweh, not Moses [or Joshua] who demands the destruction of the nations." Meyer (2011:5), in reflecting upon Josh. 10:11, also argues that:

The text is not only about YHWH ordering the Amorites to be killed, but it portrays YHWH as a warlord who takes active part in the killing and whose killing surpasses that of the Israelites.

The issue of divine participation in violent actions in the Old Testament has led many contemporary scholars to question biblical authority with regards to ethical reasoning. It becomes apparent that, particularly throughout the conquest narrative, God is portrayed as the one who not only orders the Israelites to fight, comforting them with the assurance that He Himself has "given" Jericho, Ai and the five kings of the Amorites into the hands of Israel $(6: 2 ; 8: 1,18 ; 10: 8,19,30,32)$, but also the one who prescribes the as method for their conquest (8:2). For as Josh. 11:9 clearly states: "Joshua did unto them as the LORD bade him" (KJV).

At this point it is necessary to affirm that these portrayals of a violent YHWH are not the only images used to describe the God of Israel throughout the Old Testament. In fact, such texts stand in sharp contradiction to many prophetic (and other) writings in the Hebrew Bible that clearly condemn violence, and rather plead for peace and social justice. One has to admit that within the Old Testament itself "there is considerable diversity ... when it comes to the way God is portrayed" (Seibert 2016:20). ${ }^{7}$ The question remains, however, as to why such inherently violent texts that seem to justify inhumane behaviour as divinely-sanctioned conduct, would have been written in the first place let alone would be regarded as valuable fragments in the Hebrew Bible. What is more, one also must ask how we should respond to these texts within our contemporary context.

\section{Theological responses to literary violence in the Old Testament}

Many scholars have in the past engaged with the study of the interpretation of violent texts in the Hebrew Bible. Unfortunately many of them did so only in a grand effort to minimise the theological "damage" caused by the very nature of these texts (Meyer 2011:2). On the more conservative side of the spectrum, certain interpretations lead to the performance of the same atrocious acts described throughout the texts - in the guise of scriptural authority. Accordingly, this approach seems utterly irresponsible. For even if we are to agree that violence is indeed natural to human nature, that which is considered to be natural, is not necessarily synonymous with that which is good, necessary or "legitimate before God" (Ellul 1969:127). In fact, by this misguided logic that morally justifies violence under the guise of "just cause", "scriptural authority" or the "greater good", we only promote a troubling lack of compassion for other living beings (Seibert 2016:19).

Others, who represent the other side of the hermeneutical spectrum, rather advocate that we are left with no other choice than to completely rewrite the violent biblical narratives in "an alternative canon that subverts the dominant vision of violence and 
scarcity" (Schwartz 1997:176). Cheryl Kirk-Duggan is a prime example of theologians in this regard - recommending an "open canon" as the only viable solution to the problem of the Old Testament's inherently violent nature (Kirk-Duggan 2006:13). This approach can, however, be deemed equally irresponsible as practical theological response, as it reminds of efforts akin to Marcion's rejection of the violent Old Testament God for the seemingly "loving God" of the New Testament (see Ballard 2015:6).

Alternatively, there are those such as Bauman (2006) who seems to have found a middle ground in this regard, proposing neither a total dismissal nor face value appreciation of these texts. Rather, Baumann (2006:82) proposes that although the utter barbarity of these violent texts should in no way be masked by the seemingly ethical authority of the biblical canon as holy scripture, we should ultimately still pay attention to their functioning within their intended ANE context.

The manner in which we engage with literary violence in the Bible should therefore be one of extreme caution, but still determinate action. Without giving in to a total avoidance of these horrific texts, Baumann (2006), therefore, proposes an in-depth understanding of the functioning of these texts within their specific socio-political milieu(s) as one of the only hermeneutical responses that can claim to be simultaneously "honest", responsible and, above all, practical.

Her strategy to engage actively with divine images of violence in the Bible, flows from the firm belief that these texts can and should in no way be ignored or downgraded to mere "marginal images", as Brueggemann, for example, proposed much earlier in his career. Instead, Baumann (2006:81) argues that violence plays a vital role not only in Old Testament theology, but also in human nature, and should, therefore, surely form part of our contemporary theological debates (Baumann 2006:81, cf Meyer 2011:5). In actively dealing with violent texts in the Old Testament, Baumann (2006:79-81) then proposes her own hermeneutical process, consisting of five exegetical steps. These steps can be summarised as follows: Firstly, Baumann (2006:82) argues for the careful consideration of a text's historical context - asking questions such as, What kind of violence could the authors of these texts have experienced? (Baumann 2006:81). A deeper understanding of the cultural and political contexts from which a particular text originated, inevitably prompts further investigation into possible parallels with extrabiblical ANE literature - the second step in Baumann's hermeneutical approach. This phase is then followed by a further comparison of the specific text with other texts within the same canon to expose implicit literary traditions within the Bible itself (Baumann 2006:83). The fourth step in her strategy is investigating the literary context of these violent texts, after which she finally attempts to understand the functioning thereof within its original context in order to uncover "how these texts helped the ancient authors to deal with their experiences of violence" (Meyer 2011:5).

In contrast to many scholars (Schwarts 1997; Kirk-Duggan 2006; etc.), who have only succeeded in highlighting the obvious - that the Old Testament indeed has a violent legacy we are seldom able to escape - Baumann (2006) instead manages to propose a hermeneutical response that at the very least aids the modern reader to understand the inclusion and functioning of such texts within the larger canon, without justifying their inherent troubling content. Accordingly, our own proposed response to literary violence within the Hebrew Bible leans heavily upon that of Baumann - urging the contemporary scholar to not only engage with these ethically challenging texts, but also to earnestly 
seek to understand their functioning within the original ANE context. This process entails not only a theological understanding of the texts, but also an in-depth interdisciplinary study thereof, including sociological, psychological and socio-political insights.

This proposed response could accordingly be divided into three main steps. The first is an initial exegetical study enquiring into the literary context of the text. This phase is then followed by an inquiry into the text's historical context - examining the historicity and date of the proposed narrative. Finally, insights from disciplines outside the field of theology are applied to the text to uncover the most probable functioning of the text within its original ANE context. We thus condense Baumann's five steps into three, but we also rely on insights from the social sciences.

The second part of this article will accordingly deal with the application of this proposed approach to the conquest narrative in Josh. 6-11 in order to illustrate the possible functioning of literary violence in the Hebrew Bible.

\section{Understanding the possible functioning of literary violence in Joshua 6-11}

\section{Uncovering the text's literary context}

In the Hebrew Bible the book of Joshua serves as a transition between the Torah and the Former Prophets. From its optimal perspective, it is able to look back on the promise that God made to Abraham at a much earlier time, while also being able to look ahead to Israel's occupation of Canaan (Alter 2013:12). Accordingly one could either regard the book of Joshua as having a closer relation to the former books (Genesis through Deuteronomy) or the historical books (from Deuteronomy to Kings). If the former proposition is adopted as a viable hypothesis, the book of Joshua can be interpreted as being the final segment of the Hexateuch - serving as a unification of the Pentateuch and Israel's initial occupation in Israel (Dozeman 2015:5). Scholars like Gerhard von Rad, following in the footsteps of Julius Wellhausen, pursued this theory with vigour during the earlier half of the $20^{\text {th }}$ century, arguing that the fulfilment of the divine promise made to Abraham in Gen. 15 is only fully realised in the book of Joshua, therefore inevitably binding it to the content of the first five books (Dozeman 2015:5).

While this argument seemed compelling, other Old Testament scholars such as Martin Noth (1943) later disagreed with Von Rad and finally proposed a literary understanding of Joshua that contends it is part of the literary unit he deems the Deuteronomistic History (DH) (Collins 2004b: 183; cf. Dozeman 2015:5). Noth argues that this unit of literary work was finally compiled by a single editor during the late exilic period, with the main purpose of explaining the disastrous state of affairs as divine punishment for Israel's disregard of God's law and covenant (Römer 2007:22-25; Collins 2004b:184). More recent approaches, however, dismiss both of these hypotheses and rather argue that the book of Joshua should be seen as an autonomous work of literature, distinct from the larger literary context of either the Pentateuch or the DH (Dozeman 2015:22-25). ${ }^{8}$

8 For a more detailed discussion see Römer (2007:26-43), especially his discussion of the two main schools which came after Noth, namely those of Cross and Smend. Römer is also not as quick to dismiss older hypotheses as Dozeman seems to be. 


\section{Historical context}

Although it seems that most contemporary scholars would agree that the Book of Joshua originated between the Neo-Assyrian and Persian periods, there have been differing opinions about this in the past. In fact, the thematic content of the book could suggest both an early dating around the late Monarchic period (late $7^{\text {th }}$ century BCE); or a much later date, closer to the late exilic or early post-exilic eras (Collins 2004b:184; Dozeman 2015:27). This article argues (along with Dozeman 2015:28; cf. Rowlett 1996:1) that we need to accept a long history of composition, initiated no later than the late $7^{\text {th }}$ century BCE, but only finally completed in the post-exilic period (Dozeman 2015:27-31). A similar position can be found in Römer (2007) who argues that the Deuteronomistic history probably originated in the Neo-Assyrian period and was reworked during the Babylonian and Persian periods. This is also his view of the book of Joshua (see Römer 2007:81-90, 133-136, 178-182).

Many intrinsic literary elements within the book support this perspective. For one, the violent thematic content of Joshua corresponds with the political milieu of the late $7^{\text {th }}$ century BCE. Thus Römer (2007:82-85) shows how elements of Assyrian propaganda texts appear throughout Josh. 6-12. Römer (2007:86) actually regards Assyrian propaganda as the "main source of inspiration when they composed the first version of the conquest accounts in Joshua". But Römer (2007:133-136) also believes the book was reworked during the Neo-Babylonian period when perspectives on the law were added. It accordingly becomes clear that the narrative was probably finalised during the post-exilic, Persian period (Römer 2007:180-181; Dozeman 2015:27). Texts such as Josh. 3-4 and Josh. 6 with their mix of Deuteronomistic and Priestly elements could have been "blended" in this period (Römer 2007:180).

That the narrative had a long history of development, can also clearly be seen in the repetitive sections in the book, such as Josh. 13:1 and 23:1. Dozeman (2015:32) suggests that this would mean that different existing narratives were eventually edited by multiple authors to form a single book. The same conclusion may be reached when one considers the many inconsistencies within the book itself. Some segments (see 11:21-23; 21:43$45 ; 24: 13$; etc.) refer to the Canaanite cities as being totally destroyed, while other segments still acknowledge the presence of Canaanites with Israel in the promised land (see 13:1-6; 23:1-16; etc.). These inherent ambiguities leave the modern biblical commentator with few other options than to acknowledge a long history of composition by various editors and authors, finally resulting in a completed literary work during the post-exilic era. The question, however, is raised whether there is any historical truth to the narrative. If there is not, as many contemporary scholars believe, why then does the narrative include such violent images as part of Israel's proposed history?

Along with Judges, 1-2 Samuel and 1-2 Kings, the Book of Joshua serves as our main resource in plotting ancient Israelite history (Collins 2004b:183). In saying this, however, one should acknowledge that all "historical" writing in the Bible should be regarded as utterly subjective, as it is usually comprised of a varied assortment of material, of which at least some items stem from much older oral traditions (Collins 2004b:185). Moreover, one should also take into account the fact that all historical writing in the Hebrew Bible was written within set religious traditions and ideologies, aimed at a specific audience within a specific context (Younger 1990:42; Collins 
2004b:185). This, however, should not discourage us from finding at least some historical value in these texts. For as Collins (2004b:185) argues:

We should not doubt that these writers tried to give an accurate account of the past as they understood it. But they also clearly wanted to convey a theological understanding of history, the belief that the course of events is shaped by God in response to human actions.

Many archaeological attempts to corroborate the biblical account of Josh. 6-11 with historical, scientific facts have proved utterly unsuccessful. Dever (2003:37-74) gives a rather lengthy explanation of this, all boiling down to the fact that many cities that according to the narrative were reportedly destroyed by the Israelites, show no evidence of destruction, while other cities that were in actual fact historically destroyed, are never mentioned in the biblical account. Both Jericho and $\mathrm{Ai}$, for example, were uninhabited when the Israelites supposedly conquered them (also see Collins 2004b:199-201; cf. Alter 2013:4).

Taking all of this into account, one must assume that the model of the total and bloodthirsty conquest of the land of Canaan, as described in the book of Joshua, is not historically accurate. Rather, Collins (2004b:203) proposes another likelihood regarding the way in which Israel emerged in Canaan. In what he calls "the gradual emergence model", Collins basically describes the Israelites themselves as being of Canaanite origin but gradually developing a "separate identity" that distinguished them from their earlier compatriots (Collins 2004b:190). The exact reasoning behind this Israelite movement remains unclear. However, if the archaeological evidence is considered, one must assume that the settlers in the central highlands were a group of individuals who intentionally separated themselves from the Canaanite city-states and eventually became known as the cult of YHWH (Collins 2004b:191). The more recent history by Christian Frevel (2018:77-79) presents a similar model which he calls "das Evolutionsmodell" as the most plausible.

Bearing all of this in mind, we can again turn to the question posed earlier in this article regarding the possible reasoning behind the promotion and inclusion of such violent theological ideals within the pages of the Hebrew Bible. For as Mokoena and Meyer (2019:2) rightfully state:

The problem for the contemporary reader is that when violence is attributed to and allegedly sanctioned by a deity, it could potentially incite even more violence, something that our world has already had more than enough of.

It is therefore imperative in our contemporary context that we do not shy away from the theological implications of these violent texts of the Hebrew Bible but rather engage with them in a responsible yet critical manner - responding actively, rather than passively receiving texts that were never intended to result in even more violence after the fact. However, the type of responses that will be regarded as responsible in this regard, cannot be examined without first perusing an understanding of the functioning of the conquest narrative within its original context in the first place. Some interdisciplinary theories on 
this issue will now be discussed to uncover some of the possible motives behind the production of the text.

\section{Including inter-disciplinary perspectives}

\section{Social identity theory}

Some research has been conducted on the existing relationship between religion and social identity formation (Schwartz 1997; Van Dyk 2003:96-99). This research has shown that the mere belonging to a religious community, creates and sustains a form of not only personal but also collective social identity. And even though one always embarks upon dangerous territory when applying modern interdisciplinary theories to ancient texts, most scholars agree that this relation between practising religion and the establishment of social identity was also evident in ancient Israel (Schwartz 1997; cf. Collins 2004b:193-195; Larson 2004:109). Collins (2004b:194), in fact, states that especially during the post-exilic period when the Deuteronomistic history was finalised,

... the influence of Josiah's reform played a fundamental role in the reestablishment of national identity. As Israel gradually began to emerge from the siege of Assyrian domination, their longing for self-preservation became a key motivation for their actions.

The concept of self-preservation also inherently implies "an act of self-distinguishing and separating from others, of boundary making and line drawing" (Schwartz 1997:5). In defining who we are, we accordingly also define who we are not. Henri Tajfel and John Turner, who are still regarded as the historical pioneers of social identity theory (SIT), describe humankind as naturally deriving our self-understanding from the various social categories to which we feel we "belong" (Tajfel and Turner 1986:16). Religion, specifically, functions as a semi-permanent defining agent in creating in-groups in which we feel a sense of belonging. Unfortunately, by distinguishing ourselves from others based on participation in a certain religion, those not belonging to our self-defined ingroup are perceived as "outsiders" (Tajfel and Turner 1986:17).

Referring to Israel in the post-exilic era, their construction of insider/outsider boundaries was intensified in the belief that their differentiation from others (especially from those who were in close cultural and religious proximity to them) would ensure their collective survival as a distinguishable entity (Collins 2004b:194). After exile, their newly fashioned exclusive devotion to YHWH possibly resulted in their screening themselves off from the rest of their society in order to preserve their own social identity (Collins 2004b:194). Their unifying bond was not one of culture or ethnicity, but rather of religious thought (Benjamin 2004:1). For by preserving their collective social identity, the collective survival of the group's ideas, its ideals and ideologies were also assured (Larson 2004:126).

\section{Hybridity}

Initially the concept of textual hybridity was introduced as a neologism within the field of post-colonial studies to refer to instances where themes and literary traditions of originally oppressive texts were creatively adapted by an oppressed culture in order to 
portray themselves as the supreme power. This same term was later used within the field of biblical studies in particular to describe the apparent reversal of original Neo-Assyrian texts of oppression into texts that favoured YHWH alone (Morrow 2010:356). ${ }^{9}$ When applying this logic, it becomes possible that many violent (and non-violent) texts throughout the Hebrew Bible could in fact have had their origins in well-known literature traditions of the ANE that were eventually masterfully adapted on a literary and theological level to diminish the power previously attributed to other gods in order to favour YHWH. By reformulating well-known Neo-Assyrian political texts or royal inscriptions that once served as subjugations of Judah, the authors of the DH could in fact use these texts to Israel's benefit (Morrow 2008:336).

On a psycho-social level, this textual reformulation could indeed also function as the voice of a colonised state's inner struggle between the pull of being enculturated into the superpower's ideology and their strong need to establish and maintain their own identity (Morrow 2008:336). Textual hybridity thus became a socio-political strategy that aimed not only to gain power through literature, but also to voice the experiences of the oppressed (Rowlett 1996:2).

In determining whether a biblical text can indeed serve as a possible form of textual hybridity, special attention has to be paid to the possible "borrowings of vocabulary, participation in a common intellectual culture ... genre patterns and the possibility of appropriation of textual material through written or oral transmission" (Morrow 2008:324). In other words, a commonly shared cultural and linguistic foundation, along with a familiarity with certain key schemas of a subjugator's rhetoric, is necessary in order for an oppressed culture to create hybrid texts that could eventually count in their favour.

What makes the aspect of hybridity particularly interesting with regard to the Josh. 6-11 text, is the fact that it seems not only to have aimed to reverse oppressive texts and strategies employed against them by the Assyrians, but also speaks to former repressive texts found in the Pentateuch itself. The striking similarities between the conquest narrative and the banishment from the garden of Eden were initially recognised by Don Benjamin only in 2004. For Benjamin, the symbolic value of the "commander of the army of YHWH" who is introduced in Josh. 5:13 as a soldier holding a "flaming sword", should not be underestimated. This motif employed at the banishment of Adam and Eve from Eden in Gen. 3:24 functions in both texts as indicating a "boundary between an old world and a new world" (Benjamin 2004:21). If the authors did in fact employ this imagery deliberately, yet another literary reversal of Israel's fate becomes evident. For where the warrior with his flaming sword in the Genesis narrative symbolised a boundary between a world where people once experienced freedom and their new world where they would now engage with oppression, the Joshua text reverses this image to imply the exact opposite. In this sense the text becomes a literary liberation of an oppressed people longing for freedom (Benjamin 2004:21).

9 Bhabha (1994:112) provides a useful definition of hybridity in this regard: "Hybridity is the name for the strategic reversal of the process of domination through disavowal (that is, the production of discriminatory schemas or texts that secure the "pure' and original identity of authority." 
The accrual of courage and the instilment of fear

As a final theory on the possible motives behind the compilation and canonical inclusion of a literature of violence such as the conquest narrative in the Book of Joshua within the Hebrew Bible, the psycho-social effect of the accrual of courage and the instilment of fear within the originally addressed society also needs to be examined. It is regarding this topic specifically that Rowlett (1996:12; cf. Ellul 1969:31) refers to the inherent element of threat present throughout the narrative as a possible solution to the apparent theological tension. By applying a rhetoric of violence, the Deuteronomistic authors managed to produce a narrative that served as a viable instrument to coerce, or at least encourage, its readers into submission under a government that was still in disarray (Rowlett 1996:12). Contrastingly, the same narrative also instilled a sense of courage and loyalty in a nation in desperate need of coherence and unity in a time of turmoil.

The violent overtones of religious discourse in biblical texts often testify to terror, fear, and anxiety at every turn (De Villiers 2013:2). Israel often plummeted into the depths of violence, where the Israelites faced death, destruction, or banishment at the hands of their enemies. Even from within their own religious cult, constant inter-tribal conflicts threatened their very existence. A healthy dose of "fear" served very effectively to keep both Israel and its enemies vigilant in such a violent world.

It accordingly becomes clear that Israel's portrayal of its own historical account in such an extremely violent manner could indeed have served as a method to repeatedly expose others to its ideologies - instilling fear in the hearts of anyone who considered disobeying the religious and cultural beliefs of the group. Simultaneously, the narrative also encouraged its readers to remain loyal to a supposedly victorious nation that "fought" under the command and protection of YHWH.

\section{Conclusion}

Even though up to this point the conquest narrative in Josh. 6-11 has been used as example text in this article, some of the proposed theories can indeed also be applied to many other violent texts in the Hebrew Bible. These theories aid in providing at least a foundation of information on which a responsible and critical theological response to biblical violence can be formed.

All three theories mentioned above paint ancient Israel as vulnerable. This applies whether we are talking of the late monarchical period when Judah was recovering from Neo-Assyrian oppression and produced hybrid texts inspired by terrifying Neo-Assyrian propaganda, or later in the exilic and post-exilic periods when what was left of Judah attempted to survive, first in a hostile Neo-Babylonian empire and later in a much more friendly Persian empire. In these historical contexts, theories like social identity theory, hybridity, and accrual of courage and instilment of fear, make sense. On the other hand, they remind us of the old saying that "violence begets violence".

Even if it becomes apparent that violent texts in the Hebrew Bible may have fulfilled a crucial function within ancient Israel society, and even though one has to agree that violence is a natural part of human existence, this violence should not be condoned as being ethical, necessary or divinely justified - especially not in a document that so many rely on for moral guidance. Rather, as Siebert (2016:23) encourages: 
Readers of the Bible have a right - and, indeed, a duty - to probe, question, and oppose statements that seem to them to be morally unacceptable. Far from being passive recipients of the text, they are encouraged to become active agents whose duty it is to subject the ethical implications of the Hebrew Bible to critical scrutiny.

The harmful afterlife of many violent texts in the Old Testament has resulted in too many atrocious acts being justified in the name of scriptural authority. War, slavery, racial segregation, colonialisation and the abuse of women and children, to name but a few, have plagued our societies for centuries - often based on the misuse of Scripture. To us the "other" became the Irish Catholics, the Native Americans, the Palestinians, the Africans, the immigrants, the homeless, the poor, the gays, the lesbians, etc. And in effect, not only was the character of the ANE texts lost in translation, but also the God it bears witness to.

Ellul (1969:19), however, accurately states that theology is in its very nature a science "after the fact". In other words: our theological ideas can only be formulated in the process of reflection upon things that have already happened. And we can only ever engage with biblical texts by using the available information that we have at our disposal at the time. Our hermeneutical approaches are therefore never final or unfailing. But in using the evidence currently at our disposal, it is our duty to do so responsibly. This inevitably means a critical engagement with biblical authority, especially about its inherently violent content, that does not allow for a masking of massacres in the name of JHWH.

\section{BIBLIOGRAPHY}

Alter, R. 2013. Ancient Israel: The Former Prophets - Joshua, Judges, Samuel and Kings. New York: W.W. Norton and Company.

$\mathrm{Au}, \mathrm{C} .2012$. Justice and peace for global commercial sex workers: The plight of aboriginal migrant women in Taiwan, The Ecumenical Review 64(3):16 pages.

Ballard, J.P. 2015. An apologetic for the Canaanite conquest. Unpublished paper available online: <https://works.bepress.com/jordan_ballard/24/>. Accessed 20 March 2020.

Baumann, G. 2006. Gottesbilder der Gewalt im Alten Testament verstehen. Darmstadt: WBG.

Benjamin, D.C. 2004. The Old Testament story: An introduction. Minneapolis: Fortress Press.

Bhabha, H.K. 1994. The location of culture. London: Routledge.

Boustan, R.S., Jassen, A.P. and Roetzel, C.J. 2010. Introduction. In Boustan, R.S., Jassen, A.P. and Roetzel, C.J. (eds), Violence, Scripture and textual practice in Early Judaism and Christianity. Leiden: Brill, 1-13.

Brueggemann, W. 1997. Theology of the Old Testament: Testimony, dispute, advocacy. Minneapolis: Fortress Press.

Carter, S. 1996. Making violence useful. In Bradby, H. (ed.), Defining violence. Sydney: Avebury, 135-140. 
Carr, D.M. 2010. An introduction to the Old Testament: Sacred texts and imperial contexts of the Hebrew Bible. Chichester: Wiley-Blackwell.

Clines, D.J.A. (ed.). 1996. The dictionary of classical Hebrew. Vol. 3. Sheffield: Sheffield Academic Press.

Collins, J.J. 2004a. Does the Bible justify violence? Minneapolis: Fortress Press.

Collins, J.J. 2004b. Introduction to the Hebrew Bible. Minneapolis: Fortress Press.

Collins, J.J. 2005. The Bible after Babel: Historical criticism in a postmodern age. Grand Rapids: Eerdmans.

Dever, W.G. 2003. Who were the early Israelites and where did they come from? Grand Rapids: Eerdmans.

De Villiers, P.G.R. 2013. Fear as dread of a God who kills and abuses? About a darker side of a key, but still forgotten biblical motif, HTS Teologiese Studies/ Theological Studies 69(1):9 pages.

Docker, J. 2008. The origins of violence: Religion, history and genocide. London: Pluto Press.

Dozeman, T.B. 2015. Joshua 1-12: A new translation with introduction and commentary. New Haven: Yale University Press. (AYB 6B)

Ellul, J. 1969. Violence. New York: Seabury Press.

Frevel, C. 2018. Geschichte Israels. 2. erweiterde und überarbeitete Auflage. Stuttgart: Kohlhammer.

Kirk-Duggan, C.A. 2006. Violence and theology. Nashville: Abingdon Press.

Larson, J.P. 2004. Understanding religious violence. Burlington: Ashgate Publishing Company.

Meyer, E.E. 2011. The role of the Old Testament in a violent world, Verbum et Ecclesia 32(2):8 pages.

Meyer, E.E. 2018. The חרם in Joshua 6 and 7, influenced by P?, Acta Theologica 26:71-87.

Milgrom, J. 2001. Leviticus 23-27. A new translation with introduction and commentary. New York: Doubleday. (AB 3B)

Mokoena, L.L.D. and Meyer, E.E. 2019. Jehu's violent coup and the justification of violence, HTS Teologiese Studies/Theological Studies 73(3):6 pages.

Monroe, L.A.S. 2007. Israelite, Moabite and Sabean war-herem traditions, and the forging of national identity, Vetus Testamentum 57(21):318-341.

Morrow, W. 2008. Resistance and hybridity in late bronze age Canaan, Revue Biblique 115(3):321-339.

Morrow, W. 2010. To set the name in a Deuteronomic centralization formula: A case of cultural hybridity, Journal of Semitic Studies 55(2):365-383.

Niditch, S. 1993. War in the Hebrew Bible: a study in the ethics of violence. New York: Oxford University Press.

Report of the Secretary General. 1999. The causes of conflict and the promotion of durable peace and sustainable development in Africa (Media release). Available online: <https://docs.wfp.org/api/documents/WFP-0000032029/download/html>. Accessed 20 March 2020.

Römer, T.C. 2007. The so-called Deuteronomistic History: A sociological, historical and literary introduction. London: T \& T Clark. 
Rowlett, L.L. 1996. Joshua and the rhetoric of violence. A new historicist analysis. Sheffield: Sheffield Academic Press.

Schwager, R.S.J. 2018. Must there be scapegoats: Violence and redemption in the Bible. New York: The Crossroad Publishing Company.

Schwartz, R.M. 1997. The curse of Cain: The violent legacy of monotheism. Chicago: University of Chicago Press.

Seibert, E.A. 2012. The violence of Scripture: Overcoming the Old Testament's troubling legacy. Minneapolis: Fortress Press.

Seibert, E.A. 2016. Recent research on divine violence in the Old Testament (with special attention to Christian theological perspectives), Currents in Biblical Research 15(1):8-40.

Tajfel, H. and Turner, J.C. 1986. The Social Identity Theory of intergroup behavior. In Austin,W.G. and Worchel, S. (eds), Psychology of intergroup relations. Chicago: Nelson-Hall Publishers, 33-47.

Tatlock, J.R. 2006. How in ancient times they sacrificed people: Human immolation in the Eastern Mediterranean basin with special emphasis on ancient Israel and the Near East. Unpublished Ph.D. dissertation, University of Michigan.

Van Dyk, P. 2003. Violence and the Old Testament, Old Testament Essays 6(1):96112.

Versluis, A. 2016. Devotion and/or destruction? The meaning and function of חרם in the Old Testament, Zeitschrift für die alttestamentliche Wissenschaft 128(2):179197.

Wright, J.L. 2015. Urbicide: The ritualized killing of cities in the Ancient Near East. In Olyan, S.M. (ed.), Ritual violence in the Hebrew Bible: New perspectives. New York: Oxford University Press, 147-166.

Younger, K.L. 1990. Ancient conquest accounts: A study in Ancient Near Eastern and biblical history writing. Sheffield: Sheffield Academic Press. 